\title{
ISLAM AND LOCAL CULTURE IN INDONESIA
}

\author{
Hermansyah \\ Pontianak State Institute of Islamic Studies, Pontianak
}

\begin{abstract}
Muslims believe that their religion is universal, suitable to all places and time. Consequently, in practice, Islam can be adapted to various situations and conditions. Therefore, the diversity in Islam is inevitable. Diversity is especially related to aspects of interpretation and religious branches, not things that are principle. This article is about the relationship between Islam and local culture. As recognized by many experts, Islam in Indonesia was spread by peaceful means. Local elements were used in the process of Islamization. As a result, Islam could be accepted by most of society of Indonesia. Islam expressed here shows a distinctive face. Islam can live hand in hand with local culture, especially the culture that is not incompatible with Islam.
\end{abstract}

Keywords: Islam, Islamization, local culture, diversity.

\section{INTRODUCTION}

Islam was first revealed in Mecca almost 15 centuries ago in its form in addition to showing some similarities also some differences. The similarities are especially concerned with the basic fixed and unchanged doctrine. Meanwhile diversity is more about the area of interpretation and the actualization of this religion in the world. The diversity of interpretations and it actualization appear because the religion has a critical interaction with human reality, including culture. The diversity is noticeable once we compare the actualization of Islam in different parts of the world.

In the face of local culture, Muslim scholars and educators at least generally take two attitudes. First, adjusting the pattern of da'wah and education with the current socio-cultural processes. For them, the changes of society should be done gradually according to a socio-cultural conditions of the individual people and communities. It is based on the view a person's Islamic kaffah is easy, fun and convenient for everyone else to do during their lifetime. (See Abdul Munir Mulkhan, 2002: 1). This kind of patterns usually view syncretic modernist, and traditionalist label, and the like as the stages of diversity of a person or community. This diversity is a socio-cultural process which will change along with social, economic, and cultural changes in a person or 
community. Meanwhile the second pattern emphasizes more on prohibition and threats based on belief, morals, and worship ( $i q h$ ) in order to change the behavior of a person's and community's religious behavior. The religious behavior of someone who has not been in accordance with the basic principles of Islam is called un-Islamic or sometimes other labels are given. Patterns such as these tend to be more political through the development of law and legislation.

The success of the spread and development of Islam in Indonesia has most like been due to the use of the first such pattern, and it will be outlined below. Of course the second pattern also contributes to a certain segment of society especially among the middle class especially in the period of consolidation of Islam. If we divide the Islamic practice in two models, i.e. Sharia and Sufism, then the first model is more easily accepted by merchants, employees and higher social classes. The second Model is more readily accepted by farmers, workers and communities experiencing socio-cultural transition, or industrial society that is experiencing a massive rationalization. The first model of Islamic practice is developed through Da'wah and rationalization of education, while the second through a spiritualization or Sufism.

The process of Islamization in Indonesia mostly used the second model. The success of the adherents of Sufic Islam in Indonesia's Islamization, is among others due to this pattern of Islam --in some respect-- 'fits ' with the background of local people who have been influenced the Hindu-Buddhist asceticism and Syncretism of local belief. This article elaborates on the relationship of Islam and local culture in Indonesia. This paper is primarily based on the beliefs and practices of Islam in that region that illustrate relationships and interplay between Islam and the local heritage culture.

\section{THE INTERACTIONS BETWEEN ISLAM AND LOCAL CULTURE}

Islam is believed by its followers as a religion that is suitable for any place and time. This belief among others is based on the view that Islam is a religion that fits with nature of humanity. Further implication of this view is that all the efforts and results of human creativity which correspond to the nature of humanity is Islamic in itself.

On the other hand, Muslims believe that Islam is universal. Islam's universality concerns the basic teachings and products that apply in all places and time. Islamic universality especially concerns the teaching of basic values and is believed to be originated from the revelation of God that does not change and cannot be changed. Because it only concerns the teaching of basic values and 
then not all answers the humanitarian issues have been provided technically by Islam. It is inevitably derived from the teachings of Islam when the dynamics of historical society involve the creativity of human understanding and culture where the religion comes to strengthen it. Thus the reciprocal relationship between Islam and local culture is natural.

This is in fact reinforced by the nature Islamic religion that is present not for a specific group but for all mankind. Thus Islam that was reveled in Saudi Arabia is not only articulated in the context of Arab society. Its universality can accommodate the diversity of human cultures scattered in all corners of the world. Therefore, local cultures could not and should not be omitted altogether just because the community embraces Islam. This is perhaps the meaning of the phrase al-Islam salih fi kulli makan wa fi kulli zaman.

However, not all elements of the local culture by itself are in accordance with the teachings of Islam. Of course there are incompatibilities. Elements that are contrary to the principles of Islam are what must be changed, adapted and altered or even abolished. In other words, the coming of Islam must always result in an overhaul of social transformation or heading into a better direction. Nevertheless, at the same time, the coming of Islam does not necessarily break a society from their past. Islam also can preserve what is good and right of the past and can be maintained in the test of the universality of the Qur'an. This is a long process that occurs in the spread of Islam across the world. When Islam was present and embraced by the Persian community, then we saw the results: philosophy, science of kalam, and Sufism. Similarly, in other areas, Islam's encounter with the local context has produced distinctive Islamic style.

In short, by realizing the universal dimension of Islam as well as the existence of human freedom to solve the problems, then the actualization of Islam in West Kalimantan might be different from that fellow Muslims in Java or the Middle East and other places. This sort of awareness is what makes the spreaders of Islam in Indonesia in general made use of local resources in the framework of the process of Islamization. According to the history, the King of Patani in Southern Thailand converted to Islam because he was cured by a Sheik from Pasai. In West Kalimantan, there are a lot of local mantra texts that have Islamic content as also found in the Malay Peninsula (Skeat, 1967). The acceleration of the transformation - in line with the fall of Majapahit-the Javanese feudalistic culture turned into an Islamic egalitarian society driven by the spreaders of Islam using local elements. Another example is the use of wayang (Javanese puppets) by Sunan Kalijaga, a ceremony for 'Islamized' people who recently died, and various other cultural events. This sort of phenomenon also happens everywhere. Many other traditions can be referred 
to as examples.

Researcher Abdurrahman Abror (2003) for example, found that the Malay pantun in Pontianak, is not only a spoken art passed down orally from one generation to the next, but also used to transform universal great values including specifically the values of Islam. Islam can be reconciled with the local culture. This peaceful Islamic character is recognized by many researchers of Islam in the archipelago. In contrast to the emergence of a dominant religion as Catholicism in the Philippines and Latin America since the 15th century after military conquest and abolishment of culture (Azyumardi 1999: 37). To a certain degree, it must be recognized also that the spread of Islam to Europe in the past involved military forces. As a result, Islam could not survive for a long time. This pattern of the spread of Islam only sowed some hatred that can be felt to this day called Islamophobia among most Western societies.

Before Islam came to Indonesia, the local beliefs were mostly oriented toward the supernatural forces that exist in the river, trees, hills and other places or characterized by Hindu-Buddhist influence. However after Islam arrived, the orientation shifted to Islamic belief system, though admittedly it is not fully complete yet given a number of practices are still common among the society. In view of this relationship, there are at least two types of assessment put forward by scientists.

First, they see that Islam in Indonesia, in a wider context, in the Indonesian archipelago, is syncretic nature. In this view, Islam is considered to have mixed with local culture. Islam in Indonesia is at the peripheral position, second class and not authentic. This view is represented among others by Winstedt and Geertz. Winstedt, For example, argued that the presence of this religion is nothing more than changing the name or label with Islamic nuances to the local belief system of the animists and Hindu-Buddhist in nature. Meanwhile the substance of the belief has not changed.

The second scientist argued that Islam in Indonesia is unique. For them the authenticity of Islam in this region is not necessarily congruent with Islam in Arabia. The encounter between Islam and local culture has produced a distinctive Islamic form without losing the essence and the spirit and this is inevitable. Islam here is also authentic and is on the mainstream. The scientists who supported this view, among others, are Al-Attas, Azyumardi Azra, and Woodward. According to Al-Attas (1969: 4-7) that the Malay Archipelago displacement of the belief system of the Hindu-Buddhist tradition is comparable to the transition of the Western world view which was heavily influenced the Greek mythology, to the world of reasoning and enlightenment. 
In fact, cultural changes occur continuously. As part of culture, tradition also goes through changes from time to time; or at least culture adapts to its surrounding. Such changes may apply from within those traditions or may also result from acceptance of influence of the tradition from outside. Usually changes from within the tradition take place rather slowly compared to the influence of tradition from outside.

In the context of the Islamic community in the archipelago, the change can be exemplified with the cosmology of some people who previously believed in the myth, then it was replaced with a new cosmological traditions of the empirical material and style. Of course this is not always the case or, in other words, is not applicable to the whole Islamic community of Indonesia because there are still many Islamic communities who also maintain the Islamic traditions. When looking at the relationship between Islam and local culture in Indonesia there are three patterns as can be seen in the following graph:

The GRAPHIC pattern of the relationship between tradition and Islam

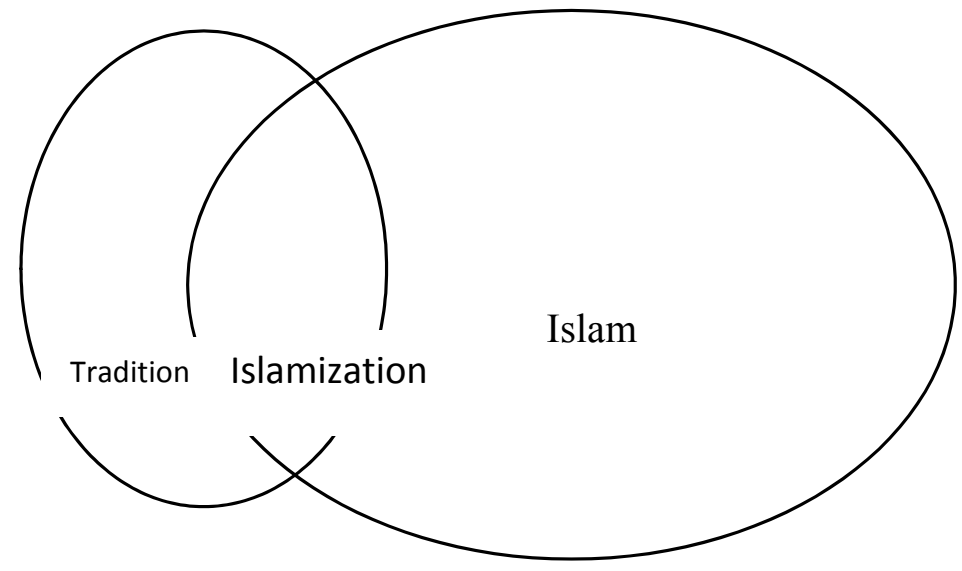

Source: Hermansyah (2010)

\section{THE FIRST PATTERN, THE ETERNAL TRADITION}

The arrival of Islam has brought many changes to the communities of Indonesia who chose to embrace the religion, including in terms of culture. As times change, especially with Islam getting stronger, some traditions are lost. Although most of the heritage of belief was still practiced in the same way it was to this day. This could be seen in a form of the tradition of animism and Hindu-Buddhism. Some communities still live their life in the way local people of the archipelago in the past did.

Some examples can be presented here. In many Islamic communities in Indonesia, we can still find ceremonies of giving sacrifice in order to obtain 
salvation. This belief is related to the belief that nature is controlled by certain supernatural creatures. Supernatural beings are believed to affect people's lives. One of the forms of this belief is common among the coastal communities where several forms of ceremonial 'feeding' of the supernatural powers considered to have control over the area are still widely performed. In some areas, people living near the sea or river often perform ceremonies of dumping food into the river or sea called buang-buang (throwing away). Similar ceremonies are performed by hanging offerings at the intersection or under a specific tree. The ceremony is in some places called hanging the ancak. The two types of traditional ceremony are relatively in the original. This kind of practice also can be easily found in non-Muslim communities.

Today, there are still many Muslims who practice traditional medicine which involves calling for invisible spirits to enter the body of a shaman as a medium to inform patients about diseases and as ways of treatment. This method is called in shamanism. The pattern of Islamic society is mainly found in villages that are a bit far from the center of the development of Islamic Da'wah and education and community groups who recently embraced Islam. This condition is reasonable since the transformation of a society usually requires a relatively long time even takes several generations to complete.

\section{THE SECOND PATTERN, THE BLEND BETWEEN ISLAM AND TRADITION OR IN THE PROCESS OF ISLAMIZATION}

In addition to the presence of inherited traditions of belief and practice still in existence without undergoing a lot of changes in the Islamic people of Indonesia, there has also been a mix between tradition and Islam teachings. The blend between the two elements - tradition and Islam-- namely the old and the new, is in the state of continuum and not a separate entity (dichotomy). In other words, in the belief and practice of Islamic societies in this area, it still contains old tradition that goes hand in hand with new elements.

The continuity of the culture is made possible due to among others the resemblance of the old culture with Islamic faith. For example belief about immortality of the spirit in the teaching of Islam is similar to the belief about life and the spirit among the people of the archipelago. For example, in one of the Dayak sub-ethnic groups in West Kalimantan particularly Dayak Taman, as reported by YC. Tambun (1998: 81-90), they believe that after death, a human'n sumangat (spirit) will live another life in several worlds and ends at the Banua So'soak and Banua Ti'asu - where the sumangat will eternal. Banua So'soak is for sumangat who did good deeds during their life and is an eternal place, while Banua Ti'asu for evil. Dayak Ngaju, the largest group of Dayak in 
Central Kalimantan, even hold a special ceremony called tiwah to deliver the spirit of someone who has died to enter a new world (Schiller, 1997). Similarly the concept of ghost among people in the archipelago has similarities with the concept of Jin and the Satan in Islamic belief.

There are many other examples that could be cited. Selamatan ceremony is practiced by many Islamic people in Indonesia. The roots of this kind of ceremony can be traced prior to the arrival of Islam. However, the Muslim community has added some nuances, modified and altered the ceremony so as to become an Islamic tradition. Another example, a lot of spells and the like which are practiced by local Muslims are visibly to be derived from local sources but at the same time have been enriched by Islam (see Hermansyah, 2006, 2010).

Conversely there are also Islamic belief and rituals that have been mixed with local traditions. Many of the teachings of Islam are gaining local color in their expression. The Indonesian Muslims hold a lot of ceremonies such as childnaming, circumcision, wedding, and funeral which are the application of Islamic teachings, and in practice they get an extra local color. There are a lot of variations in the implementation of the ceremonies.

The efforts of the scholars and former educators to incorporate the elements of Islam into local traditions or vice versa were not actually meant to reinforce existing traditions. It was the first step to introduce Islam to those who had not known anything about the religion. This is a tiered effort. As a result of this process of Islamization, Islam was accepted by the entire community of the Indonesian archipelago.

This is not surprising because as described Azyumardi Azra (1999) that Islam could be propagated up to remote places in the country thanks to the teachers and the sufi travellers who moved from one place to another to spread it. The presence of the Sufis is acceptable because, to a certain extent, the sufis are more tolerant and even take advantage of local traditions as a means to Islamize the society. Research conducted by Hermansyah $(2006,2010)$ found that the practices among the sufis were similar those of the communities in the Indonesian archipelago especially with regard to magic, which in the local language is called ilmu (Malay) or ngelmu (Java). For example, among the followers of Sadziliah in Egypt believe that certain chants have magic power, like hizb al-bahr which was used as a spell of protection during a trip (Schimmel 1976: 178). Similarly, the role of Islamic religious figures 'kiyai' in Java is important in terms of the belief in magic as in the determination of the wedding day (Vredenbregt 1990: 62); So is the case with the santri (students of Islamic Boarding School) who use verses from the Quran for the purposes of 
treatment as reported by Geertz (1989: 118-119)

Similarly, the spreaders of Islam in Indonesia, especially the sufis, were also believed to have the ability to heal in a way unseen so it caught the attention of the local community who then sympathized with and embraced Islam. For them, the sufi figure could fulfill their pragmatic interests. Therefore, Islam embraced by most of the people in the archipelago in the early stages of Islamic period in this region, is actually still alive in the mental world inherited by local culture and gave birth to the syncretic style of Islam. In this light, Lapidus (1991: 487-488) stated that while many Muslims adhered to the high tradition defined by ulema and Sufi teachings, many, if not most lived in a mental world defined by the heritage of local cultures. For most Southeast Asian villagers, Islam was an element of a more complex social and religious identity and not the exclusive symbol of personal and collective life.

In contrast to the traders or the trade world which generally is centered on the coastal areas that are open and cosmopolitan, the sufi travelers/teachers penetrated the interior areas which have agrarian culture and typical cosmopolitan views. Sufi masters have inclusive views or weltanschaung, and distinctive agrarian culture that tend to be syncretic. Islam no longer appears in strict exclusivism as a religion of revelation; but it is quite accommodating to local values and belief systems that have been established. This is also recognized by researchers from outside who found that the encounter between Islam and traditional beliefs was the secret to the success of Islam in the Indonesian Archipelago (see Lapidus 1991: 468, Bellah 2000).

\section{THE THIRD PATTERN, “PURE ISLAM”}

As pointed out above that some of the old traditions and beliefs still existed without any influence from Islamic teachings. There are also traditions that are interwoven with elements of Islam. In the implementation, Islamic elements indicated 'victory' over the traditions. The teachings of Islam - especially its formal aspects - increasingly showed dominance over local traditions, especially those that are contrary to Islam. Many aspects of local belief and practice have been abandoned and replaced entirely by the teachings of Islam. However, all forms of practices of local beliefs that have no conflict with the principles of Islam are retained and even reinforced. Thus the "purity" of Islam in Indonesia remains in typical space and time.

As an example of such a pattern is the teaching about cleanliness. In West Kalimantan, for example, the implementation of thaharah (body cleaning) which is called a "balimau" bath or a "srotu" bath on the upper Kapuas River 
is a typical local thaharah practice. Practices like this in no way contain elements of trust locally, just use a distinctive way. Another example of local belief concerning ghosts is slowly replaced by Islamic belief about the Jinn and devils. Beliefs about semangat (spirit) was replaced with faith about the spirit and the soul (nafs). There is also the spirit of local culture and practices that are maintained as it in line with Islam such as family, community, and tolerance originally passed on by the ancestors are retained by the Muslims here.

Muslims in Indonesia choose the sarong --commonly also worn Buddhist people in other parts of Southeast Asia as clothing and the white skullcap made in China to cover the head when going to mosque-- are not necessarily less faithful compared to their fellow Muslims who wear robes and turban when going to the Masjid al-Haram in Mecca. Similar clothing that is worn also by some Christian communities in Africa to go to church, because it is their everyday clothes.

Earlier scholars continued good traditions that already existed in the community completely departing from an understanding of Islamic teachings. Isn't this religion the successor of the traditions of Abrahamic religions? Islam is not entirely new. Muslims are told to believe in the past Abrahamic religious teachings and set things straight and leave the teachings that are in contrary to the basic principles of Islam (for example: QS. al-Baqarah [2]: 41, 89, 91, 97, 101; Ali Imran [3]: 3; al-An'aam [6]: 92).

Based on this belief, the establishment of Islamic law should follow the principles of al-muhafazhah 'ala al-qadim al-shalih wa al-akhdz bi al-jadid al-ashlah (holding on to the old and good one, and to the better new one) and al-adah al-muhakkamah (customs that could be a basis of the law), which are derived from good habits that grow and flourish within the community, as long as they are in line with the basic principles of the Qur'an and Sunnah.

"Purifying" Islam - in the context of locality — in Indonesia and various other parts of the world is experiencing rapid development in line with the increase in Da'wah and education. Scholars have contributed to the improvement of the quality of the Islamic community. Even lately there are also movements of "purification" of Islam which are less likely to appreciate the locality. For supporters of this form of Islamic movement, pure Islam means that it must be congruent with Islam in its native land.

\section{CONCLUSION}

Belief and practice as part of the culture that existed in the Islamic society 
of Indonesia now are not something that grew and flourished in an empty space. All of this existed as a continuity of treasure of humanity. Derivation and redirection of a tradition towards the formation of a new, more complex culture is reasonable and necessary. There is no culture and civilization in the world that is built without relationship and interaction with other cultures and civilizations.

The diverse Islamic actualizations are historical facts in a socio-cultural process, where Islam develops. The spread and development of Islamic Da'wah and education through the efforts by utilizing local culture should not draw the line between 'pure Islam' and 'syncretic Islam' but it should accelerate change through empowerments or socio-economic advocacy and education. Ways of spreading and developing patterns of Islamic teachings which tend to demean other people's faiths, could be counter productive.

The pattern of the spread and development of Islam that emphasizes bans and threats based on faith, morals, and worship ( $f i q h)$ in order to change the religious behavior is relevant with community with better level of education, of course with an emphasis on the mauizah al-hasanah method.

The Indonesia Muslims are being tested to resolve various problems facing this nation. The religion and the people being tested on which religion pattern can significantly bring Indonesia to become better nation. This "history test" will prove whether (the pattern of) Islam chosen and practiced by the majority of the people of this nation will bring Indonesia toward success or otherwise.

\section{BIBLIOGRAPHY}

Abdul Munir Mulkhan. 2002. "Dakwah Kultural dalam Tradisi Keberagamaan di Indonesia," paper presented at Sidang Tanwir Muhammadiyah di Denpasar Bali 24-27 Januari.

Abdurrahman Abror. 2003. Pantun Etnik Melayu Pontianak. Disertasi pada Universiti Malaya.

Attas, Syed M. Naquib al-. 1969. Preliminary statement on general theory of Islamization of Malay-Indonesia Archipelago. Kuala Lumpur: Dewan Bahasa dan Pustaka.

Azyumardi Azra. 1999. Renaisans Islam di Asia Tenggara,Sejarah Wacana \& Kekuasaan. Bandung: Remaja Rosdakarya.

Bellah, Robert N. 2000. Beyond belief: menemukan kembali agama, esei-esei tentang agama di dunia modern. Terj. Rudy Harisyah Alam. Jakarta: Paramadina. 
Geertz, C. 1989. Abangan, Santri, Priyai dalam Masyarakat Jawa. Jakarta: Pustaka Jaya.

Geertz, C. 1989. Abangan, santri, priyai dalam masyarakat Jawa. Jakarta: Pustaka Jaya.

Hermansyah. 2006. Alam Orang Melayu: Kajian Ilmu di Embau, Kalimantan Barat Indonesia. Disertasi Doktor pada Institut Alam dan Tamadun Melayu, Universiti Kebangsaan Malaysia.

Hermansyah. 2010. Ilmu Gaib di Kalimantan Barat. Jakarta: Gramedia, EFEO, STAIN, KITLV.

Hermansyah. 2013. Islam dan Toleransi Beragama dalam Masyarakat Muslim Kanayatn Dayak Kalimantan Barat. Dalam. Islamica. Vol. 7. No. 2. Maret. Hal 340-359.

Lapidus, Ira M. 1991. A history of Islamic societies. Cambridge: Cambridge University Press.

Malinowski, B. 1961. The Dynamics of Culture Change. New York: Yale University Press.

Nurcholish Madjid. 1992. Islam Doktrin dan Peradaban: sebuah telaah kritis tentang masalah keimanan, kemanusiaan dan kemodernan, Jakarta: Paramadina.

Schiller, Anne. 1997. Small sacrifices: Religious change and cultural identity among the Ngaju of Indonesia. New York, Oxford: Oxford University Press.

Skeat, W.W. 1967. Malay magic: being an introduction to the folklore and popular religion of the Malay Peninsula. New York: Dover Publication. [First published 1900]

Vredenbregt, Jacob. 1990. Bawean dan Islam. Jakarta: INIS.

Winstedt, R.O 1985. The Malay Magician being shaman, saiva and sufi. Kuala Lumpur: Oxford University Press.

Woodward, Mark R. 1989. Islam in Java: normative piety and mysticism in sultanate of Yogyakarta. Tucson: University of Arizona Press.

YC. Thambun Anyang. 1998. Kebudayaan dan perubahan Daya Taman Kalimantan dalam arus modernisasi. Jakarta: Grasindo dan KITLV.

Yusriadi. 2002. "Fenomena Masuk Islam di Kalimantan Barat: Menyusuri etimologi Lubuk Melayu." Khatulistiwa. 2. Hal. 1-12. 
